\title{
Single-Incision Slings (SIS) - \\ a New Option for the Surgical Treatment of Female Stress Urinary Incontinence
}

\section{Single-Incision-Schlingen (SIS) - neue Entwicklungen in der operativen Behandlung der Belastungsinkontinenz der Frau}

Authors

Affiliation
G. Naumann, S. Albrich, C. Skala, R. Laterza, H. Kölbl

Universitätsmedizin Mainz, Klinik und Poliklinik für Geburtshilfe und Frauenheilkunde, Mainz

\section{Key words \\ - single incision sling \\ - success rate \\ - complications \\ - new surgery}

Schlüsselwörter

- Single-Incision-Schlinge

- Erfolgsrate

- Komplikationen

- neue OP-Techniken

\section{received 23.10.2011 \\ revised 11.12.2011 \\ accepted 12.12.2011}

\section{Bibliography}

DOI http://dx.doi.org/

10.1055/s-0031-1298275

Geburtsh Frauenheilk 2012; 72:

125-131 @ Georg Thieme

Verlag KG Stuttgart · New York . ISSN 0016-5751

\section{Correspondence}

\section{Dr. G. Naumann}

Universitätsmedizin Mainz

Klinik und Poliklinik für Geburts-

hilfe und Frauenheilkunde

Langenbeckstraße 1

55131 Mainz

gnaumann@uni-mainz.de

\section{Abstract \\ $\nabla$}

The new development of single-incision slings (SIS) for the treatment of female stress urinary incontinence offers comparable results with only minimal side effects and will find wide acceptance in modern incontinence surgery. This minisling is inserted over a single vaginal incision and fixed on both sides to the pelvic wall tissue with special anchors, without passing through the groin and avoiding a blind tape passage. Compared with the established sub-urethral tapes, there are comparable success rates with fewer complications. Randomised prospective studies are needed to evaluate whether, in the long run, the benefits of the single incision technique can be correlated with satisfying continence results.

\section{Introduction \\ $\nabla$}

With a prevalence of up to $35 \%$, the number of cases of female stress urinary incontinence requiring operative treatment has risen drastically in recent years. On the one hand, there is growing public awareness of the problem, with increasing freedom from taboos, and increasing willingness of the affected women to undergo therapy. On the other hand, newer operative techniques and materials with a trend towards minimally invasive methods have been developed over the past 15 years.

The successful application of synthetic, tensionfree vaginal slings with punctum maximum in midurethra, an implementation of the integral theory of Ulmstem and Papa Petros, has been confirmed in several studies with LoE I and II. Since 1995, more than five million tapes have been im-

\section{Zusammenfassung \\ $\nabla$}

Die Neuentwicklung von Single-Incision-Schlingen (SIS) bei der operativen Therapie der Belastungsinkontinenz der Frau ist mit vergleichbaren Kontinenzraten und nur geringsten Nebenwirkungen verbunden und kann in Zukunft breite Anwendung in der Inkontinenztherapie finden. Diese minimalinvasiven Schlingen werden über eine singuläre vaginale Inzision eingebracht und bds. an der Beckenwand über verschiedene Haltesysteme verankert. Bei gleicher Wirkung durch suburethralen Bandsupport wird hier jedoch eine Blindpassage wie bei den bekannten retropubischen oder transobturatorischen Systemen vermieden. Im Vergleich zu den etablierten suburethralen Schlingen zeigen sich in den ersten Untersuchungen äquivalente Erfolgsraten und deutlich geringere Nebenwirkungen. Hierzu müssen prospektive Studien die Wertigkeit im Vergleich zu den etablierten Verfahren noch belegen.

planted around the world, making this the most frequently performed of all incontinence operations. In the meantime, over 16 years, there have been numerous modifications to one of the materials and the insertion aids, and differing sub-urethral access paths for insertion have been developed.

In respect to the material, there is a clear consensus: the tapes used are of polypropylene material, type I in accordance with the amide classification of 1994. This monofilamentous and macroporous material has a pore size $>75 \mu \mathrm{g}$ and is characterised by fewer reactions from foreign bodies and infections. Rejection reactions and persistent infections can therefore be practically disregarded. 


\section{We Differentiate between Different Access Paths:} $\boldsymbol{\nabla}$

\section{Retro-pubic route}

First described in 1996 by Ulmsten, the retro-pubic route was the original passage for tension-free tapes according to the currently existing conventional sling method. The retro-pubic approach with introduction of the tape via a small colpotomy in the midpart of the urethra and in supra-symphysary design (bottom-top $=$ TVT $^{\circledR}$ plastic, Gynecare) has been used the longest and has the most study results. Current data from 2008, with a follow-up time of 11.5 years, confirm the high efficiency of the method, with an objective continence rate of $90 \%$, a subjective continence rate of $77 \%$ and an improvement of $20 \%$ (LoE II) [1]. According to a Cochrane analysis, the retro-pubic route with needle guided from the abdomen to the vagina (top-bottom, e.g. Sparc ${ }^{\circledR}, A M S$ ) shows a poorer continence rate compared with the TVT $^{\circledR}(77$ vs. $82 \%$ ).

A number of studies comparing TVT and other incontinence operations exist. Burch colpo-suspensions and retro-pubic slings give equally good success rates in respect to continence and negligible side effects, even after five years, LoE I [2].

The retro-pubic passage entails risks and side effects; here, for example, one can mention bladder lesion rates of $3-4 \%$ and possible lesions affecting the intestine, blood vessels or nerves on the pelvic wall. Overall, large national complication registers, such as the Finnish register of Kuuva (2002) [3] or the Austrian register of Tamussino (2001) [4], show negligible and acceptable side effects. However, they also report severe problems, including death.

\section{Trans-obturator approach}

The trans-obturator route introduced by Delorme in 2001 avoids the retro-pubic path and passes the obturator fossa on both sides, but also requires a distinct blind passage.

In a comparison by Latthe et al. between retro-pubic and transobturator routes in 2007, no significant differences were found in terms of the continence rate; however, significant differences were found in the examination of the side effects and complications. In the TVT group, there were more bladder lesions and micturition disturbances due to obstruction. At the same time, the trans-obturator method resulted in significantly more vaginal erosions and pain syndromes, with dyspareunia and trouble bending the legs [5].

A recent comparison by Latthe at al. of the trans-obturator method with the TVT- $\mathrm{O}^{\circledR}$ (Gynecare) as an inside-out (introduction from the vagina to the abdomen) or Monarc ${ }^{\circledR}$ (AMS) as an outside-in (introduction from outside and leading towards the vagina) reported similar success rates, but indicated differences in terms of side effects and complications. With the inside-out method, there were fewer bladder lesions and fewer micturition disturbances, but more pain syndromes. With the outside-in method, there were significantly more vaginal sulcus injuries [6].

\section{Single-incision slings = mini-slings (SIS)}

Since the end of the 1990s, developments have also taken place concerning the use of the first mini-slings, which showed still less invasiveness due to a singular access. With these new systems, blind passage is vastly reduced; that is, the tape is not blindly inserted retro-pubically or via the obturator foramen. At the same time, this utilises a considerably shorter sling of around $6.5-12 \mathrm{~cm}$, thereby introducing less foreign material. The objective is to achieve adequate continence rates compared with the established sling methods, with a further significant reduction of possible complications.

- Table 1 lists the single-incision slings available on the market together with their specific properties.

Initially, different tapes were used, including bio-materials with non-ready-to-use insertion aids. For this reason, the classification of the initial data is very difficult today.

In 1999, Palma et al. introduced the tendinous urethral support System (TUS system), using a sub-urethral sling of bio-material. A bovine pericardium mini-sling was inserted vaginally in $10 \mathrm{pa}-$ tients and anchored on both sides to the tendinous arch. Following an initially high success rate after four weeks, distinct infections and erosions, with an incontinence rate of $50 \%$, were found after one year [7]. In a subsequent trial, a porcine sling made from small bowel sub-mucosa was used. Here again, initially there were high continence rates; initial results after six months with 25 patients indicated a good continence rate of $87 \%$, dropping to $65 \%$ after 72 months $[8,9]$. With the use of synthetic tape materi-

Table 1 List of the available single-incision slings.

\begin{tabular}{|c|c|c|c|c|c|c|}
\hline Tape & Manufacturer & Material & Length & Insertion aid & Attachment & Adjustability \\
\hline DynaMesh ${ }^{\circledR}$ minor & $\begin{array}{l}\text { FEG Textiltechnik mbH, } \\
\text { Aachen, Germany }\end{array}$ & $\begin{array}{l}\text { PVDF } \\
\text { monofilament }\end{array}$ & $6 \mathrm{~cm}$ & no & $\begin{array}{l}\text { self-adhesive } \\
\text { surface }\end{array}$ & no \\
\hline TFS $^{\circledR}$-System & $\begin{array}{l}\text { TFS Surgical, Adelaide, } \\
\text { Australia }\end{array}$ & $\begin{array}{l}\text { Polypropylene } \\
\text { monofilament }\end{array}$ & variable & yes & anchors & yes \\
\hline Solyx ${ }^{\circledR}$ & $\begin{array}{l}\text { Boston Scientific, Natick, } \\
\text { MA, USA }\end{array}$ & $\begin{array}{l}\text { Polypropylene } \\
\text { monofilament }\end{array}$ & $9 \mathrm{~cm}$ & yes & barbs & no \\
\hline Minitape ${ }^{\circledR}$ & Gyneldas, Glasgow, UK & $\begin{array}{l}\text { Polypropylene } \\
\text { monofilament }\end{array}$ & $14 \mathrm{~cm}$ & yes & anchors & no \\
\hline Contasure Needleless ${ }^{\circledR}$ & $\begin{array}{l}\text { Neomedic Int., Barcelona, } \\
\text { Spain }\end{array}$ & $\begin{array}{l}\text { Polypropylene } \\
\text { monofilament }\end{array}$ & $11.4 \mathrm{~cm}$ & $\begin{array}{l}\text { no } \\
\text { clamp }\end{array}$ & $\begin{array}{l}\text { self-adhesive } \\
\text { pocket system }\end{array}$ & no \\
\hline TVT-secur $^{\circledR}$ & $\begin{array}{l}\text { Gynecare/Ethicon, } \\
\text { Somerville, NJ, USA }\end{array}$ & $\begin{array}{l}\text { Polypropylene } \\
\text { monofilament }\end{array}$ & $8 \mathrm{~cm}$ & yes & $\begin{array}{l}\text { vicryl and PDS } \\
\text { anchor tips }\end{array}$ & no \\
\hline MiniArc-Precise ${ }^{\circledR}$ & $\begin{array}{l}\text { AMS, Minnetonka, MN, } \\
\text { USA }\end{array}$ & $\begin{array}{l}\text { Polypropylene } \\
\text { monofilament }\end{array}$ & $8.5 \mathrm{~cm}$ & yes & anchors & no \\
\hline Ajust $^{\circledR}$ & $\begin{array}{l}\text { C. R. Bard Inc., Murray Hill, } \\
\text { NJ, USA }\end{array}$ & $\begin{array}{l}\text { Polypropylene } \\
\text { monofilament }\end{array}$ & $6.5 \mathrm{~cm}$ & yes & anchors & yes \\
\hline Ophira ${ }^{\circledR}$ & $\begin{array}{l}\text { Promedon, Cordoba, } \\
\text { Argentina }\end{array}$ & $\begin{array}{l}\text { Polypropylene } \\
\text { monofilament }\end{array}$ & $\begin{array}{l}3.8 \mathrm{~cm} \\
\text { mesh }\end{array}$ & yes & barbs & no \\
\hline
\end{tabular}


al, Palma was able to achieve a success rate of $88 \%$ and an improvement of 5.5 in 20 women in 2005 [10].

Since 2005, commercial systems with pre-fabricated slings and standardised insertion aids have been available on the market. - Table 2 summarises the study results from this time onwards. In 2005, Petros et al. [11] introduced the tissue fixation system (TFS), using a multi-filamentous polypropylene mini-sling, which was fixed in the muscle tissue underneath the symphysis. In a follow-up of nine months, a continence rate of $83.4 \%$ was determined with 36 patients without additional complications. A subsequent telephone survey three years later of 31 of these women indicated a continence rate of $80 \%$ and $6.5 \%$ improvement. In a prospective, randomised study by Sivaslioglu et al. (2009), the TFS system was compared with an outside-in TOT sling. In a follow-up time of 36 months, the TFS group $(n=39)$ showed a success rate of $90 \%$, compared with $84 \%$ for the TOT group $(n=38)$. 12 women in the TOT group (31.5\%) had distinct pain symptoms during inguinal extensor movements [13]. Currently, there are no further relevant German publications or evidence of expansion of this system in Germany.

Since 2006, a number of different ready-made systems with further simplification of the tape system have been developed in order to encourage their widespread use. As with the conventional tension-free slings, the Type I propylene material has gained widespread acceptance. These systems are inserted into the vagina by a small colpotomy and are generally guided and attached via both sides of the obturator internus muscular fasciae in the obturator membrane directly, or less frequently, retro-pubically. This attachment is implemented either by absorbable patches, such as TVT Secur ${ }^{\circledR}$ (Gynecare), by a self-adhesive surface, such as DynaMesh SIS ${ }^{\circledR}$ minor (FEG Textiltechnik mbH), or otherwise by mini-anchor systems, such as MiniArc Precise ${ }^{\circledR}$ (AMS), Ajust ${ }^{\circledR}$ (Bard) or Ophira ${ }^{\circledR}$ (Promedon). With a tape length of around 6.5 to $8.5 \mathrm{~cm}$, the blind passage and accompanying possible complications are reduced to a minimum.

\subsection{TVT Secur (Gynecare)}

The TVT S system was the first widely used mini-sling system since 2006. A tape of around $8 \mathrm{~cm}$ in length with absorbable patches at the end is fixed with a fine metal lance to both sides in a U-form retro-pubically or in an $\mathrm{H}$-form (hammock) trans-obturatorically ( $\bullet$ Fig. 1). A release mechanism frees the tape from the inserter. The initial clinical euphoria with good success rates was followed by a sobering decline in its use. The reasons were the poorer results in the long term and some problems with serious outcomes such as distinct haemorrhaging.

An unsolved problem with all mini-sling systems is the method of applying tension to the inserted tape. In the, up to now, entirely tension-free TVT insert, particularly the TVT Secur showed considerably poorer results; a significant improvement in the continence rate was observed only with the introduction of a less tension-free insertion of the tape with contact to the urethra and without additional interspace.

The data available from the literature vary between 40 and $87 \%$ [14-20]. Investigations in our own hospital showed a continence rate of $63 \%$, with $23 \%$ improvement. However, recent data from 2010 indicate overall high efficiency, with continence rates of more than $80 \%$ and negligible side effects. In 2010, Tincello et al. introduced a TVT S global register with a total of 676 patients from 29 centres and, in a 12 month follow-up, found an objective continence rate of $84.8 \%$ with overall minimal complications [22]. The data from Han et al. [23] from the first two years also

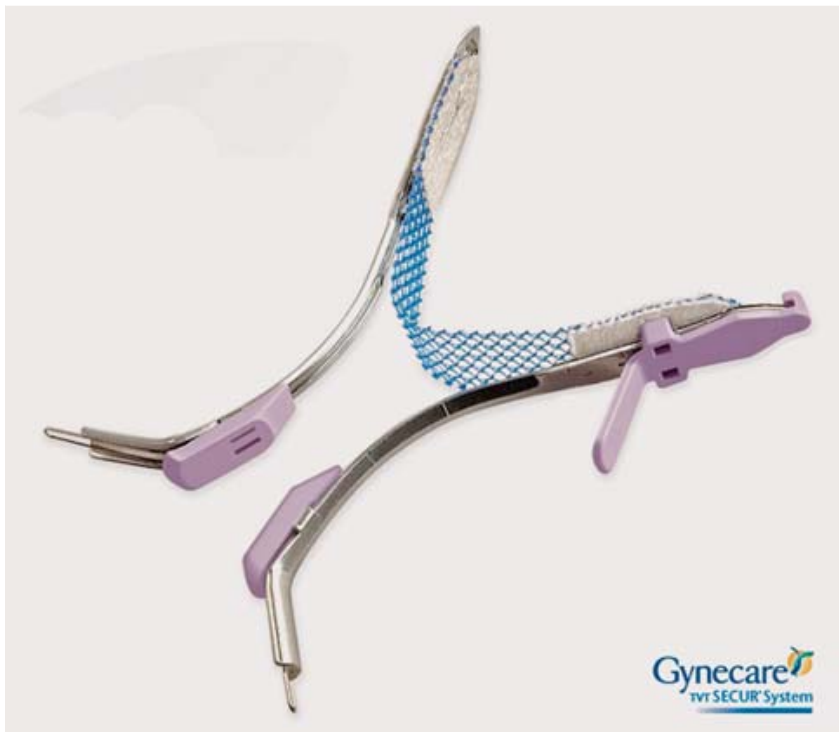

Fig. 1 TVT Secur ${ }^{\circledR}$ sling (Gynecare).

show a good success rate of $82.6 \%$. A current review by Walsh (2011) [24] evaluates 10 studies with a total of 1178 patients and a minimum follow-up time of 12 months. The review reports a subjective and objective continence rate of $76 \%$, with better results obtained when employing an insert in a "U"-form. In Germany, there are no current publications.

\subsection{MiniArc Precise ${ }^{\circledR}$ (AMS)}

The MiniArc system utilises a distinctly smaller insertion aid. Here, the tape with a length of around $8 \mathrm{~cm}$ is attached by two anchors, on both sides in the obturator internus muscular fasciae. In a further development to the MiniArc Precise ${ }^{\circledR}$, the tape is fixed to the insertion needle by a special attachment mechanism and freed by a special release mechanism ( $\bullet$ Fig. 2 ). This system can be comfortably inserted, shows only minimal side effects and is particularly convincingly because it is practically pain free, which would also allow insertion under local anaesthesia.

Current publications from 2010 and 2011 report that the method is highly efficient, is without significant side effects, and has a success rate of $82-93 \%$ [20,21,25-31]. Although this tape, due to the specific length and the defined attachment points, cannot be subsequently adjusted, problems such as obstruction, residual urine formation or urgency occur with the same negligible frequency as with the established slings. Compared with the established trans-obturator method, the MiniArc Precise ${ }^{\circledR}$ shows the same good success rates [20-21,27-28].

In the meantime, the first study results of a two-year follow-up period have been published. These results also indicate high success rates in the long-term (one-year follow-up 84-93.5\% continence rate, two-year follow-up $82-93 \%$ continence rate) $[21,26$, $28,31]$.

\subsection{Ajust $^{\circledR}$ (C. R. Bard Inc.)}

In 2008, the Ajust ${ }^{\circledR}$ sling, another single-incision sling, was introduced. This system is inserted with a special arcuate inserter and attached by a special anchor directly to the membrane of the obturator foramen ( Fig. 3). The special feature with this system is the direct, intra-operative bilateral adjustability of the tape. The two anchors are placed and the tape is then loosened and tight- 
Table 2 List of the different studies on the use of single-incision slings (SIS) with success rates and complication rates.

\begin{tabular}{|c|c|c|c|c|c|c|c|}
\hline Author & Year & System & Study & Number & Follow-up & Success rate & Complications \\
\hline Palma [7] & 1999 & TUS & prospective & 10 & 12 months & $50 \%$ & $\begin{array}{l}\mathrm{n}=2 \text { removing tape due to infection } \\
\mathrm{n}=3 \text { tape extrusion }\end{array}$ \\
\hline Palma [8] & 2001 & TUS & retrospective & 25 & 6 months & $87 \%$ & \\
\hline Palma [9] & 2007 & & & & 72 months & $65 \%$ & \\
\hline Petros [11] & 2005 & TFS & retrospective & 36 & 9 months & $83.4 \%$ & $\begin{array}{l}\mathrm{n}=1 \text { granuloma due to incorrect } \\
\text { attachment }\end{array}$ \\
\hline Petros [12] & 2009 & TFS & retrospective & 31 & 36 months & $\begin{array}{l}80 \% \\
6.5 \% \text { improve- } \\
\text { ment }\end{array}$ & $\begin{array}{l}\text { telephone survey } \\
31 \text { of } 36 \text { from [11] }\end{array}$ \\
\hline \multirow[t]{3}{*}{ Sivaslioglu [13] } & 2009 & TFS & $\begin{array}{l}\text { randomised } \\
\text { clinical trial }\end{array}$ & 39 & 36 months & $90 \%$ & $\mathrm{n}=1$ incorrect attachment \\
\hline & & TOT & & 38 & & $84 \%$ & $\mathrm{n}=2$ residual urine \\
\hline & & & & & & & $\mathrm{n}=12$ groin pain \\
\hline \multirow[t]{5}{*}{ Debodinance [14] } & 2009 & TVT-S ${ }^{\circledR}$ & prospective & 154 & 12 months & $70.3 \%$ continence & $\mathrm{n}=5$ haemorrhaging \\
\hline & & & & & & $\begin{array}{l}11 \% \text { improve- } \\
\text { ment }\end{array}$ & $\mathrm{n}=1$ bladder lesion \\
\hline & & & & & & & $\mathrm{n}=21$ residual urine $>100 \mathrm{ml}$ \\
\hline & & & & & & & $\mathrm{n}=2$ unattached tape \\
\hline & & & & & & & $\mathrm{n}=7$ injury to the vaginal sulcus \\
\hline \multirow[t]{4}{*}{ Lee [15] } & 2010 & TVT-S ${ }^{\circledR}$ & prospective & $144 U$ & 12 months & $87.5 \%$ & $\mathrm{n}=2$ residual urine formation \\
\hline & & & & $141 \mathrm{H}$ & 12 months & $80.1 \%$ & $\mathrm{n}=3$ residual urine formation \\
\hline & & & & & & & $\mathrm{n}=3$ injury to the vaginal sulcus \\
\hline & & & & & & & $\mathrm{n}=2$ haemorrhaging $>500 \mathrm{ml}$ \\
\hline \multirow[t]{2}{*}{ Liapsis [16] } & 2010 & TVT-S $\varsigma^{\circledR}$ & prospective & $39 U$ & 12 months & $71.8 \%$ obj. cont. & \\
\hline & & & & $43 \mathrm{H}$ & 12 months & $62.8 \%$ obj. cont. & \\
\hline \multirow[t]{2}{*}{ Tommaselli [17] } & 2010 & TVT-S ${ }^{\circledR}$ & prospective & 37 & 12 months & $83.8 \%$ & $\mathrm{n}=1$ tape erosion \\
\hline & & TVT-O ${ }^{\circledR}$ & & 38 & 12 months & $81.6 \%$ & $\mathrm{n}=3$ leg pain; $\mathrm{n}=2$ residual urine \\
\hline \multirow[t]{3}{*}{ Cornu [18] } & 2010 & TVT-S ${ }^{\circledR}$ & prospective & 45 & 1 month & $62.2 \%$ & $\mathrm{n}=10$ post-operative pain \\
\hline & & & & & 6 months & $53.3 \%$ & $\mathrm{n}=5$ de novo urgency \\
\hline & & & & & 30.8 months & $40 \%$ & \\
\hline Khandwala [19] & 2010 & TVT-S ${ }^{\circledR}$ & retrospective & 141 & 14.1 months & $83.0 \%$ subj. cont. & $\mathrm{n}=5$ unattached tape \\
\hline \multirow[t]{4}{*}{ Oliveira [20] } & 2011 & TVT-S ${ }^{\circledR}$ & prospective & 30 & 12 months & $67 \%$ & $\mathrm{n}=3$ de novo urgency \\
\hline & & TVT-O ${ }^{\circledR}$ & & 30 & & $83 \%$ & $\begin{array}{l}\mathrm{n}=3 \text { de novo urgency, } \mathrm{n}=2 \text { split tape } \\
\mathrm{n}=2 \text { groin pain }\end{array}$ \\
\hline & & $\operatorname{Mini} \operatorname{Arc}^{\circledR}$ & & 30 & & $87 \%$ & $\mathrm{n}=3$ de novo urgency \\
\hline & & & & & & & $\mathrm{n}=1$ groin pain \\
\hline \multirow[t]{3}{*}{ Oliveira [21] } & 2011 & TVT-S ${ }^{\circledR}$ & prospective & 25 & 24 months & $\begin{array}{l}63 \% ; 13 \% \\
\text { improvement }\end{array}$ & \\
\hline & & TVT-O ${ }^{\circledR}$ & & 24 & & $\begin{array}{l}82 \% ; 7 \% \\
\text { improvement }\end{array}$ & \\
\hline & & $\operatorname{Mini} \operatorname{Arc}^{\circledR}$ & & 25 & & $\begin{array}{l}87 \% ; 7 \% \\
\text { improvement }\end{array}$ & \\
\hline Tincello [22] & 2010 & TVT-S ${ }^{\circledR}$ & prospective & 676 & 12 months & $\begin{array}{l}81.4 \% \text { subj. } \\
84.8 \% \text { obj. }\end{array}$ & $\begin{array}{l}n=1 \text { bladder lesion } \\
n=4 \text { haemorrhaging }>500 \mathrm{ml} \\
n=2 \text { residual urine formation } \\
n=16 \text { de novo urgency }\end{array}$ \\
\hline \multirow[t]{3}{*}{ Han [23] } & 2010 & TVT-S $S^{\circledR}$ & prospective & 94 & 6 months & $89.4 \%$ & $\mathrm{n}=1$ bladder lesion \\
\hline & & & & 77 & 12 months & $88.3 \%$ & $\mathrm{n}=3$ vaginal perforation \\
\hline & & & & 23 & 24 months & $82.6 \%$ & $\mathrm{n}=2$ tape extrusion \\
\hline Walsh [24] & 2011 & TVT-S ${ }^{\circledR}$ & review & 1178 & 12 months & $\begin{array}{l}76 \% \text { subj. } \\
76 \% \text { obj. }\end{array}$ & $\begin{array}{l}1.5 \% \text { vaginal perforation } \\
2.4 \% \text { tape erosion } \\
10 \% \text { de novo urgency } \\
2.3 \% \text { micturition disturbances }\end{array}$ \\
\hline Kennelly [25] & 2010 & $\operatorname{Mini} \operatorname{Arc}^{\circledR}$ & prospective & 188 & 12 months & $90.6 \%$ & $\begin{array}{l}n=3 \text { injury to the vaginal sulcus } \\
n=5 \text { de novo urgency } \\
n=6 \text { pain } \\
n=4 \text { dyspareunia }\end{array}$ \\
\hline Kenelly [26] & 2011 & $\operatorname{MiniArc}{ }^{\circledR}$ & prospective & 142 & 24 months & $85 \%$ & \\
\hline \multirow[t]{5}{*}{ De Ridder [27] } & 2010 & $\operatorname{MiniArc}{ }^{\circledR}$ & retrospective & 75 & 12 months & $85 \%$ & $\begin{array}{l}n=3 \text { groin pain } \\
n=5 \text { de novo urgency }\end{array}$ \\
\hline & & Monarc $^{\circledR}$ & & 56 & & $89 \%$ & $\mathrm{n}=1$ haemorrhaging $>500 \mathrm{ml}$ \\
\hline & & & & & & & $\mathrm{n}=1$ erosion \\
\hline & & & & & & & $\mathrm{n}=2$ groin pain \\
\hline & & & & & & & $\mathrm{n}=8$ de novo urgency \\
\hline
\end{tabular}




\begin{tabular}{|c|c|c|c|c|c|c|c|}
\hline Author & Year & System & Study & Number & Follow-up & Success rate & Complications \\
\hline \multirow[t]{2}{*}{ Enzelsberger [28] } & 2010 & MiniArc ${ }^{\circledR}$ & prospective & 45 & 24 months & $82 \%$ & $\begin{array}{l}\mathrm{n}=1 \text { erosion } \\
\mathrm{n}=2 \text { de novo urgency }\end{array}$ \\
\hline & & Monarc $^{\circledR}$ & & 45 & & $86 \%$ & $\begin{array}{l}n=1 \text { erosion } \\
n=2 \text { de novo urgency } \\
n=1 \text { required therapy for haematoma } \\
n=11 \text { groin pain }\end{array}$ \\
\hline Oliveira [29] & 2011 & MiniArc ${ }^{\circledR}$ & prospective & 105 & 12 months & $\begin{array}{l}80 \%, 11 \% \mathrm{im}- \\
\text { provement }\end{array}$ & $\mathrm{n}=7$ de novo urgency \\
\hline Pickens [30] & 2011 & MiniArc ${ }^{\circledR}$ & prospective & 120 & 12 months & $94 \%$ & $\begin{array}{l}\mathrm{n}=3 \text { bladder lesions } \\
\mathrm{n}=1 \text { tape loosening } \\
\mathrm{n}=5 \text { de novo urgency }\end{array}$ \\
\hline Pickens [31] & 2011 & MiniArc ${ }^{\circledR}$ & prospective & 108 & 24 months & $93 \%$ & $\mathrm{n}=5$ de novo urgency \\
\hline Naumann [32] & 2010 & Ajust $^{\circledR}$ & prospective & 52 & 12 months & $86.5 \%$ & $\begin{array}{l}\mathrm{n}=1 \text { intra-operative new tape } \\
\mathrm{n}=114 \text { days post-operative new tape }\end{array}$ \\
\hline Naumann [33] & 2011 & Ajust $^{\circledR}$ & prospective & 51 & 24 months & $\begin{array}{l}82.4 \% \\
4 \% \text { improvement }\end{array}$ & $\begin{array}{l}\mathrm{n}=4 \text { no follow-up } \\
\text { no complications }\end{array}$ \\
\hline Meschia [34] & 2011 & Ajust $^{\circledR}$ & prospective & 111 & 6 months & $91.4 \%$ obj. cont. & $\begin{array}{l}\mathrm{n}=6 \text { intra-operative new tape } \\
\mathrm{n}=1 \text { tape cutting due to residual urine } \\
\mathrm{n}=9 \text { de novo urgency }\end{array}$ \\
\hline Abdel-Fattah [35] & 2011 & Ajust $^{\circledR}$ & prospective & 90 & 12 months & $\begin{array}{l}80 \% \text { subj. cont. } \\
6 \% \text { improvement }\end{array}$ & $\begin{array}{l}\mathrm{n}=1 \text { intra-operative new tape } \\
\mathrm{n}=2 \text { tape erosion }\end{array}$ \\
\hline Palma [10] & 2008 & Ophira $^{\circledR}$ & retrospective & 20 & 12 months & $88 \%$ & none \\
\hline Palma [36] & 2010 & Ophira ${ }^{\circledR}$ & prospective & 91 & 12 months & $90.2 \%$ & $\begin{array}{l}\mathrm{n}=3 \text { mesh exposure } \\
\mathrm{n}=1 \text { tape loosening } \\
\mathrm{n}=1 \text { tape cutting }\end{array}$ \\
\hline Serels [39] & 2010 & Soly $x^{\circledR}$ & retrospective & 63 & 6.5 months & $95 \%$ & none \\
\hline \multirow[t]{2}{*}{ Tardiu [40] } & 2011 & $\begin{array}{l}\text { Contasure } \\
\text { Needleless }\end{array}$ & prospective & 72 & 12 months & $87.5 \%$ & $\begin{array}{l}n=1 \text { haemorrhaging }>500 \mathrm{ml} \\
n=1 \text { bladder lesion } \\
n=1 \text { post-operative pain } \\
n=4 \text { residual urine }\end{array}$ \\
\hline & & TVT-O ${ }^{\circledR}$ & & 60 & & $90 \%$ & $\begin{array}{l}\mathrm{n}=1 \text { bladder lesion } \\
\mathrm{n}=7 \text { post-operative pain } \\
\mathrm{n}=3 \text { residual urine }\end{array}$ \\
\hline Navazo [41] & 2009 & $\begin{array}{l}\text { Contasure } \\
\text { Needleless }\end{array}$ & retrospective & 120 & 24 months & $\begin{array}{l}84 \% \\
8 \% \text { improvement }\end{array}$ & $\mathrm{n}=1$ sling extrusion \\
\hline
\end{tabular}

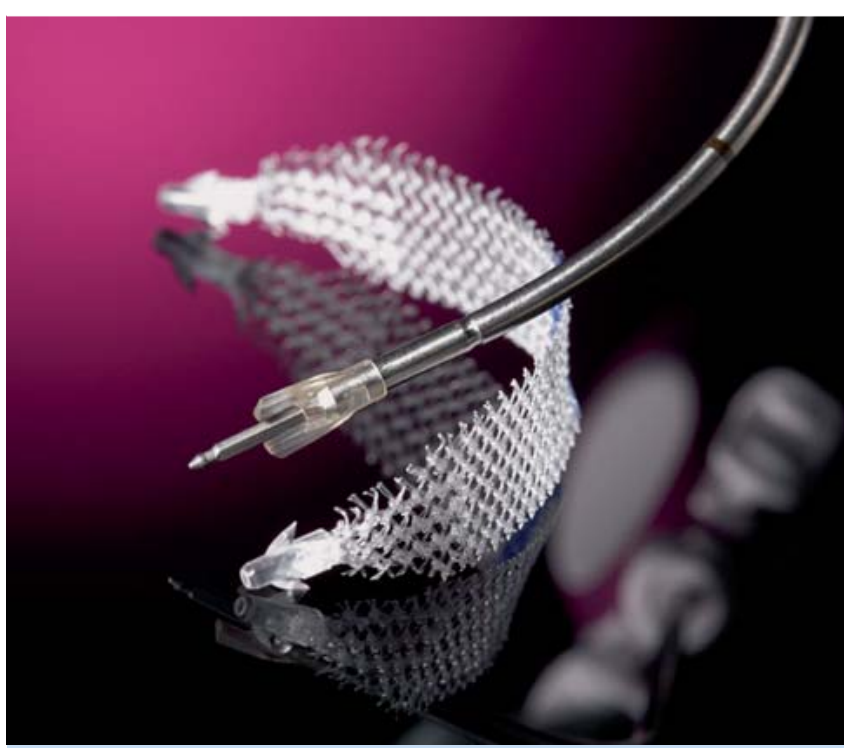

Fig. 2 MiniArc Precise ${ }^{\circledR}$ sling (American Medical Systems).

ened as required on the basis of a mesh extension in order to adapt to the optimal tape length for the individual.
The developers of this system were able to insert the first tape world-wide in 2008 and were able in 2009 to report on the data from the first 12 months, which showed a good continence rate of $86.5 \%$ and no complications. Continued observation after 24 months confirmed the high success rate, with results of $82 \%$ [32, 33]. Meschia et al. [34] again confirm these results in a prospective study with a follow-up time of six months, reporting an objective continence rate of $91.4 \%$, and an on-going, 2011 prospective study from Abdel-Fattah [35] indicates $80 \%$ subjective continence after 12 months and the possibility of surgically inserting under purely local anaesthesia.

\subsection{Ophira ${ }^{\circledR}$ (Promedon)}

The Ophira ${ }^{\circledR}$ mini-sling employs anchoring arms with numerous barbs. A thin insertion aid positions the tape and can be disconnected without problems ( $\bullet$ Fig. 4).

To date, there is a lack of publications with convincing data. In 2008, Palma et al. published the first data with a success rate of $88 \%$ after 12 months for 20 patients [10]. A more recent prospective analysis of the same group of 91 women reports a continence rate of $90.4 \%$ without side effects after 12 months [36]].

In a first review published in 2010 [37], the data for $n=2734$ TVT Secur $^{\circledR}, \mathrm{n}=557$ Miniarc $^{\circledR}$ and $\mathrm{n}=30$ Ajust $^{\circledR}$ were evaluated. Success rates of $70-80 \%$ were determined, which at the present time is slightly less than rates for the established sling systems. The 


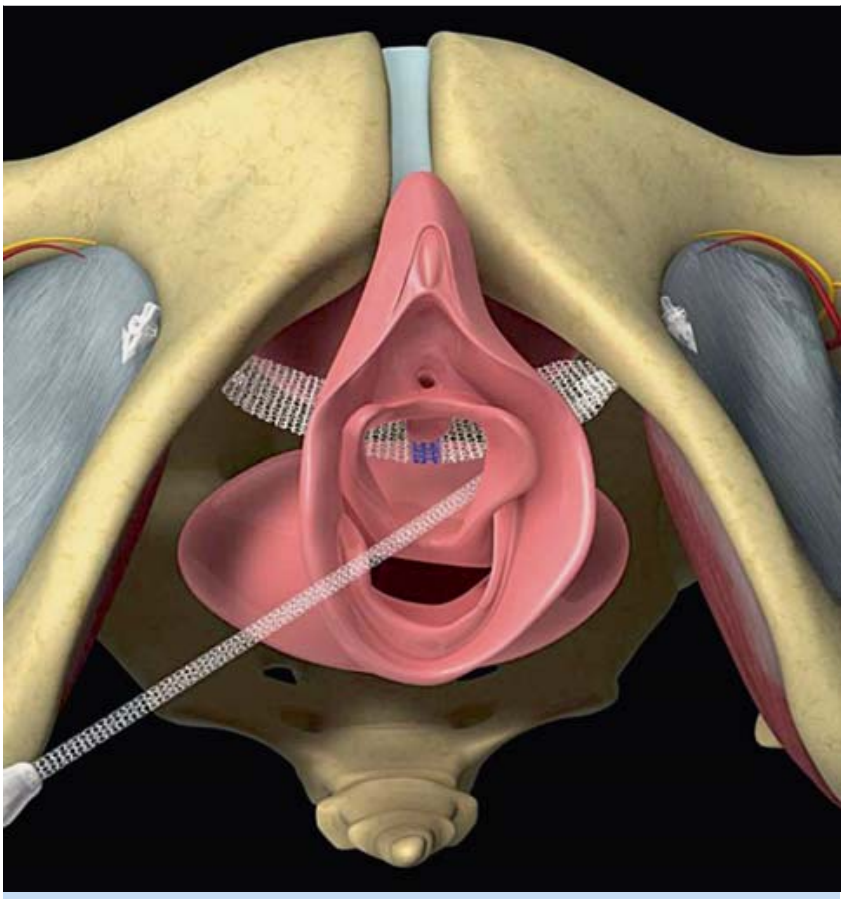

Fig. 3 Ajust $^{\circledR}$ sling (C. R. Bard).

problem here is evidently the requirement of a somewhat less tension-free insertion of the tapes, which only achieves full effectiveness when the tape is in contact with the urethra. The analysis also included early studies from this learning phase. At the same time, however, the complication rates were found to be minimal; the bladder perforation rate was $0.45 \%$ (compared with $3-4 \%$ with the TVT or TOT), with a de novo urgency of $6.6 \%$ and $0.65 \%$ for inguinal extensor complaints. Another review from Abdel-Fattah in 2011 [38] summarising nine randomised clinical trial studies and comparing single-incision slings with conventional slings $\left(n=548\right.$ TVT Secur ${ }^{\circledR}, n=160 \operatorname{MiniArc}^{\circledR}$ and $n=50$ Ophira ${ }^{\circledR}$ ) confirms this trend. Here also, the success rates of the single-incision slings were only slightly lower, with reduced side effects.

\subsection{Other single-incision slings}

Besides the mini-slings employed widely in Germany described here, there are also other types of slings. The Solyx ${ }^{\circledR}$ system also utilises a small insertion aid and the tape is fixed with barbs. Initial analyses indicate high success rates and no side effects [39].

With the Contasure Needleless ${ }^{\circledR}$ system, the sling is attached with a clamp to both sides by a pocket with a self-adhesive surface. Even without fixed attachment, the results are also between 84 and $87 \%$, however bladder lesions and post-operative pain were also reported $[40,41]$.

\section{Practical Notes for the Use of Single-Incision Slings \\ $\nabla$}

The short-term and long-term data available to date for the new single-incision slings allow us to assume that the success rates with these instruments is comparable with those of established slings. At the same time, however, initial analysis underscores the significantly reduced side effect rate and complication rate due to the lack of a blind passage for fixation of the sling.

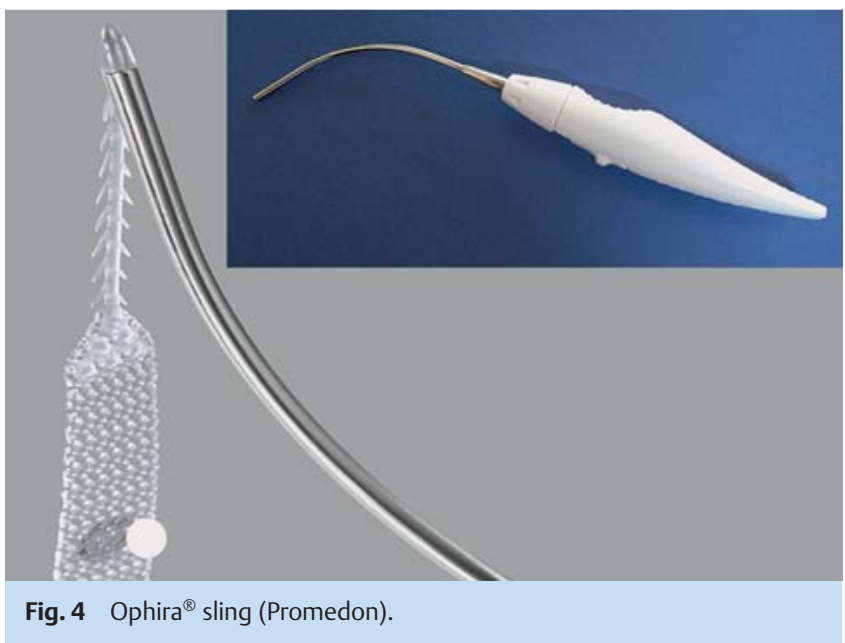

So far, retro-pubic and trans-obturator established slings have shown equivalent results and, to the same extent, a negligible rate of various complications.

For certain indications, a specific access path is clearly favoured. In the presence of intrinsic closure weakness of the urethra, the retro-pubic access path gives significantly better results. For preoperative interventions in the retro-pubic region, the trans-obturator access path is clearly preferable.

In the opinion of the authors, single-incision slings will be able to replace trans-obturator slings in the long term or sooner. With stable fixation, a tape passage in the obturator foramen is then no longer necessary; therapy for the particular problems occurring here, such as haemorrhaging, infection or nerve lesions, is very difficult.

\section{Advantages of mini-incision slings}

- further dramatic reduction of possible complications

- practically pain-free insertion of the tape, possible even under local anaesthesia

- use of less foreign material

\section{Possible indications for single-incision slings}

- operative correction for female stress urinary incontinence

- avoids retro-pubic passage during pre-operative interventions

- suitable for use with patients with a higher morbidity (e.g. adiposity, increased risk of haemorrhaging, pre-operative vaginal interventions)

- patients with mixed incontinence

\section{Conclusion for Practice \\ $\nabla$}

Single-incision slings combine the proven functional principle of sub-urethral slings with a high success rate and the advantages of using less foreign mesh material, while virtually eliminating the blind passage during insertion.

Our experience in recent years with single-incision sling for women requiring surgery for stress incontinence has been good, in particular for those women with a high operative risk, previous operations in the retro-pubic space, an increased tendency to haemorrhaging or excessive scar formation. Particularly evident are the greatly reduced invasiveness of the mini-slings and the low rate of pain symptoms. 


\section{Conflict of Interest}

\section{G. Naumann gives lectures for AMS and Bard.}

\section{References}

1 Nilsson CG, Palva K, Rezapour M et al. Eleven years prospective followup of the tension-free vaginal tape procedure for treatment of stress urinary incontinence. Int Urogynecol J 2008; 19: 1043-1047

2 Ward KL, Hilton P; UK and Ireland TVT Trial Group. Tension-free vaginal tape versus colposuspension for primary urodynamic stress incontinence: 5-year follow up. BJOG 2008; 115: 226-233

3 Kuuva N, Nilsson CG. A nationwide analysis of complications associated with the tension-free vaginal tape (TVT) procedure. Acta Obstet Gynecol Scand 2002; 81: 72-77

4 Tamussino KF, Hanzal E, Kölle D et al. Tension-free vaginal tape operation: results of the Austrian registry. Obstet Gynecol 2001; 98 (5 Pt 1): 732-736

5 Latthe PM, Foon R, Toozs-Hobson P. Transobturator and retropubic tape procedures in stress urinary incontinence: a systematic review and meta-analysis of effectiveness and complications. BJOG 2007; 114: 522-531

6 Latthe PM, Singh P, Foon R et al. Two routes of transobturator tape procedures in stress urinary incontinence: a meta-analysis with direct and indirect comparison of randomized trials. BJU Int 2010; 106: 68-76

7 Palma PCR. "Sling" tendineovaginal de pericárdio bovino. Experiència inicial. J Bras Ginec 1999; 109: 93-97

8 Palma PCR, Riccetto CLZ, Herrmann V et al. Tendinous vaginal support (T.V.S.) using the porcine small intestine submucosa (SIS): a promising anatomical approach for urinary stress incontinence. J Urol 2001; 165: 5 (A)

9 Palma P, Riccetto CLZ, Fraga R et al. Long term follow-up of the tendineus urethral support: an anatomical approach for stress urinary incontinence. Actas Urol Esp 2007; 31: 759-762

10 Palma P, Riccetto CLZ, Reges R et al. Arcus to arcus microsling: technique and preliminary results. Int Urogynecol J 2008; 19: 1133-1136

11 Petros PE, Richardson PA. Midurethral tissue fixation system sling - a 'micro-method' for cure of stress incontinence - preliminary report. Aust N Z J Obstet Gynaecol 2005; 45: 372-375

12 Petros PE, Richardson PA. Midurethral tissue fixation system (TFS) sling for cure of stress incontinence -3 year results. Int Urogynecol J 2008; 19: 869-871

13 Sivaslioglu AA, Unlubilgin E, Aydogmus $S$ et al. A prospective randomized controlled trial of the transobturator tape and tissue fixation system minisling in 80 patients with stress urinary incontinence -3 year results. Pelviperineology 2010; 29: 56-59

14 Debodinance P, Amblard J, Lucot JP et al. TVT-Secur: prospective study and follow-up at 1 year about 154 patients. J Gynecol Obstet Biol Reprod 2009; 38: 299-303

$15 \mathrm{Kim}$ JJ, Lee YS, Lee KS et al. Randomized comparative study of the U- and $\mathrm{H}$-type approaches of the TVT-Secur procedure for the treatment of female stress urinary incontinence: one-year follow-up. Korean J Urol 2010; 51: 250-256

16 Liapis A, Bakas P, Creatsas G. Comparison of the TVT-Secur system "hammock" and " $U$ " tape positions for management of stress urinary incontinence. Int J Gynaecol Obstet 2010; 111: 233-236

17 Tommaselli GA, Di Carlo C, Gargano Vet al. Efficacy and safety of TVT-O and TVT-Secur in the treatment of female stress urinary incontinence: 1-year follow-up. Int Urogynecol J 2010; 21: 1211-1217

18 Cornu JN, Sébe P, Peyrat L et al. Midterm prospective evaluation of TVTSecur reveals high failure rate. Eur Urol 2010; 58: 157-161

19 Khandwala S, Jayachandran C, Sengstock D. Experience with TVT-Secur sling for stress urinary incontinence: a 141 case analysis. Int Urogynecol J 2010; 21: 767-772

20 Oliveira $R$, Botelho F, Silva $P$ et al. Exploratory study assessing efficacy and complications of TVT-O, TVT-Secur and MiniArc: results at 12 month follow-up. Eur Urol 2011; 59: 940-944

21 Resende A, Oliveira R, Botelho F et al. Mid-term follow-up of a randomized trial comparing TVT- ${ }^{\circledR}$, TVT-Secur ${ }^{\circledR}$ and Mini-Arc ${ }^{\circledR}$. 26th Annual Congress of the European Association of Urology; March 18-22, 2011 Vienna, Abstract
22 Tincello D, Lucente $V$, Khandwala $S$ et al. One year results from a worldwide registry of TVT-Secur ${ }^{\circledR}$ in women with stress urinary incontinence (SUI). ICS/IUGA Meeting 2010. Neurourol Urodyn 2010; 29: Abstract 160

23 Han J, Lee HN, Park CM et al. The durability of efficacy of the TVT-SECUR procedure for treatment of female stress urinary incontinence: twoyear follow-up. ICS/IUGA Meeting 2010. Neurourol Urodyn 2010; 29: Abstract 738

24 Walsh CA. TVT-Secur mini-sling for stress urinary incontinence: a review of outcomes at 12 months. BJU Int 2011; 108: 652-657

25 Kennelly MJ, Moore R, Nguyen JN et al. Prospective evaluation of a single incision sling for stress urinary incontinence. J Urol 2010; 184: 604609

26 Kennelly M, Moore R, Siegel S et al. Two years prospective evaluation of the MiniArc ${ }^{\circledR}$ single incision sling for treatment of stress urinary incontinence. J Urol 2011; 185: CD Abstract 1335

27 De Ridder D, Berkers J, Deprest J et al. Single incision mini-sling versus a transobturator sling: a comparative study on $\operatorname{MiniAr}^{\circledR}$ and Monarc ${ }^{\circledR}$ slings. Int Urogynecol J 2010; 21: 773-778

28 Enzelsberger H, Cemer I, Enzelsberger S et al. MiniArc ${ }^{\circledR}$ versus Monarc ${ }^{\circledR}$ a prospective randomized study of the treatment of female stress urinary incontinence with a follow-up of 2 years. Geburtsh Frauenheilk 2010; 70: 499-502

29 Oliveira $R$, Botelho F, Silva $P$ et al. Single-incision sling system as primary treatment of female stress urinary incontinence: prospective 12 months data from a single institution. BJU Int 2011; 108: 1616-1621

30 Pickens RB, Klein FA, Mobley JD et al. Single-incision mid-urethral sling for treatment of female stress urinary incontinence. Urology 2011; 77: 321-324

31 Pickens RB, Stewart AF, White WM et al. Long term follow-up data on the MiniArc ${ }^{\mathrm{TM}}$ single incision sling system for the treatment of stress urinary incontinence. 75th Annual Meeting of the South Eastern Section of the American Association of Urology; March 17-20, 2011, Abstract

32 Naumann G, Hagemeier T, Zachmann $S$ et al. Ajust ${ }^{\mathrm{TM}}$ fully adjustable single incision sling for the treatment of stress urinary incontinence: 1 year follow-up on a new minimal-invasive treatment for female SUI. ICS/IUGA Meeting 2010. Neurourol Urodyn 2010; 29: Abstract 751

33 Naumann G, Hagemeier T, Zachmann $S$ et al. Ajust ${ }^{\mathrm{TM}}$ fully adjustable single incision sling for the treatment of stress urinary incontinence: 24 months follow-up on a new minimal-invasive treatment for female SUI. Int Urogynecol J 2012; in press

34 Meschia M, Barbacini P, Baccichet R et al. Short-term outcomes with the Ajust ${ }^{\mathrm{TM}}$ system: a new single incision sling for the treatment of stress urinary incontinence. Int Urogynecol J 2011; 22: 177-182

35 Abdel-Fattah M, Agur W, Abdel-All M et al. Prospective multi-centre study of adjustable single-incision mini-sling (Ajust ${ }^{\circledR}$ ) in the management of stress urinary incontinence in women: 1 -year follow-up study. BJU Int 2011; 26: DOI: 10.1111/j.1464-410X.2011.10471.x

36 Palma P, Riccetto CLZ, Castro R et al. Safety and efficacy of Ophira mini sling system in an outpatient basis: one-year follow up of a multicentre international clinical trial. ICS/IUGA Meeting 2010. Neurourol Urodyn 2010; 29: Abstract 751

37 Jeffery S, Acharyya R, Algar $M$ et al. Mini-sling procedures in stress urinary incontinence: a systematic review of efficacy and complications. ICS/IUGA Meeting 2010. Neurourol Urodyn 2010; 29: 811-812

38 Abdel-Fattah M, Ford JA, Lim CP et al. Single-incision mini-slings versus standard midurethral slings in surgical management of female stress urinary incontinence: a meta-analysis of effectiveness and complications. Eur Urol 2011; 60: 468-480

39 Serels S, Douso M, Short G. Preliminary findings with the Solyx singleincision sling system in female stress urinary incontinence. Int Urogynecol J 2010; 21: 557-561

40 Amat I, Tardiu L, Martínez Franco E et al. Contasure-Needleless ${ }^{\circledR}$ compared with transobturator-TVT ${ }^{\circledR}$ for the treatment of stress urinary incontinence. Int Urogynecol J 2011; 22: 827-833

41 Navazo R, Moreno J, Hidalgo C et al. Contasure Needleless: a single incision TOT for the surgical treatment of stress urinary incontinence. Arch Esp Urol 2009; 62: 719-723

Deutschsprachige Zusatzinformationen mit deutschem Text online abrufbar unter: www.thieme-connect.de/ejournals/toc/gebfra. 